\title{
Bukkal mukozada lipom: vaka raporu
}

\section{Buccal soft tissue lipoma: a case report}

\author{
smail Şener, DDS, PhD, ${ }^{a}$ Emel Bulut, DDS, PhD, ${ }^{a}$ Cihan Bereket, DDS, PhD,${ }^{a}$ Akif Türer, DDS ${ }^{\mathrm{a}}$ \\ ândokuz Mayıs Üniversitesi, Diş Hekimliği Fakültesi, Ağız, Diş ve Çene Cerrahisi AD, Samsun
}

\section{ÖZET}

Lipomlar, çoğunlukla ince bir fibröz kapsül ile çevrili olgunlaşmı̧ adipositlerden oluşan benign mezenşimal neoplazmlardır. Lipomlar en yoğun olarak 40 yaş ve üzerinde görülür. Maksilofasiyal bölgede en sık yerleştiği kısım bukkal mukoza olarak bildirilmiştir. Bunu sırasıyla dil, ağız tabanı, dudaklar izler. Oral kavitede lipomların en sik görüldüğü bölgeler yanak, dil, damak, mandibula ve dudaktır ve genellikle sapsız ya da kapsüllü bir kitle olarak gözlenirler.

$\mathrm{Bu}$ olgu raporunda 6 aydır sağ alt vestibülde ağrısız şişliği bulunan, 58 yaşında erkek hasta sunulmuştur. Lezyon normal mukoza ile çevrili ve sınırlanmış olarak görülmekteydi. Hasta lokal anestezi altında opere edildi. Histopatolojik inceleme sonucunda lipom tanısı doğruland.

Anahtar Kelimeler: Lipom, erişkin adipositler, vestibülde ağrısız şişlik.

\begin{abstract}
Lipomas are benign mesenchymal neoplasms composed of mature adipocytes, usually surrounded by a thin fibrous capsule. The most common location for lipomas in the maxillofacial region has been reported as the buccal mucosa and the peak incidence age for lipoma is 40 years and above. In the oral cavity, the most common sites are the cheek, tongue, palate, mandible and lip where lipomas occur as sessile or encapsulated masses.

The present study reports a case of a 58-year-old man presented with a painless mass in the right vestibule that had been present for 6 months. The lesion was covered by normal mucosa, seemed to be circumscribed. Under local anesthesia, excision was performed. Histopathological examination was consistence with the diagnosis of a lipoma.
\end{abstract}

Keywords: Lipoma, mature adipocytes, painless mass in vestibule.

\section{G R Ş}

Lipomlar, çoğunlukla ince bir fibröz kapsül ile çevrili olgunlaşmış adipositlerden oluşan benign mezenşimal neoplazmlardır. ${ }^{1}$ Lipomların \% 15-20'si baş ve boyun kısmında görülür. ${ }^{2}$ Bunların $\%$ 1-4'ü oral kavitede yer alır $^{2-3}$ ve genellikle tek bir lezyon olarak izlenirler. ${ }^{4}$ Oral kavitede sapsız ya da kapsüllü bir kitle olarak gözlenirler ve en sık görüldüŭgu

\section{Akif TÜRER}

Ondokuz Mayıs Üniversitesi

Diş Hekimliği Fakültesi

A ̆̆ız, Diş ve Çene Cerrahisi AD,

55139 ---- / Samsun / Türkiye

Telefon: + 903623121919

Faks: + 903624576032

E-mail: akifturer@gmail.com bölgeler yanak, dil, damak, mandibula ve dudaktır. $^{2}$

Lipomlar daha çok 40 yaş ve üzerinde görülür. Maksilofasiyal bölgede en sik yerleştiği bölge bukkal mukoza olarak bildirilmiştir. $^{4,5}$ Bunu sırasıyla dil, ağız tabanı, dudaklar izler. ${ }^{3-6}$ Neredeyse her zaman benign ve yavaş gelişim gösteren bu tümörler, yumuşak, hamur hissi ile karakterize ağrısız, yuvarlak ve hareketli bir kitle olarak izlenir.

\section{OLGU SUNUMU}

58 yaşındaki erkek hasta sağ alt vestibül bölgede 6 aydır var olan $3 \times 3 \mathrm{~cm}$ boyutlarında ağrısız bir kitle ile kliniğimize 
başvurdu (Resim 1). Lezyon görünüm olarak normal mukoza ile çevrili ve sinırlıydı. Palpasyonda sertti ve fluktan değildi.

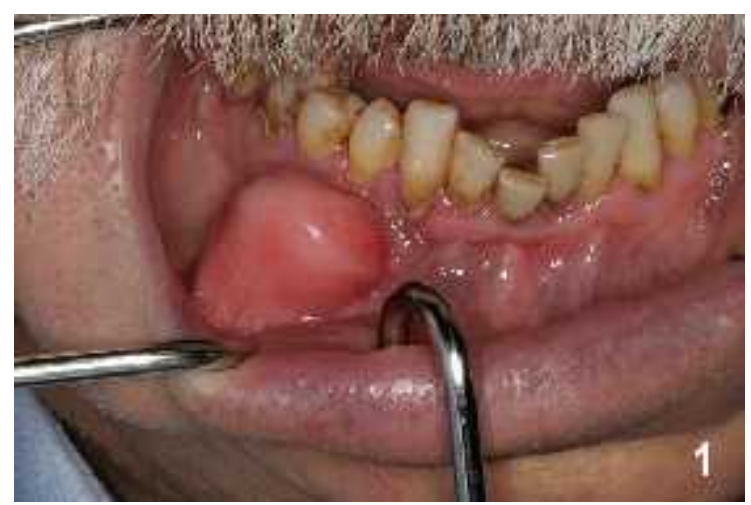

Resim 1. Să̆ alt vestibüler bölgedeki lezyonun preoperatif görüntüsü.

Hastanın lokal anestezi altında opere edilmesine karar verildi. Anestezi sonrası lezyon üzerinden mukozal insizyon yapıldı ve ortaya sarımsı, lobüllü bir kitle çıktı (Resim 2). Kapsülle çevrelenmiş klasik adipoz doku görünümü teşhis olarak lipomu düşünmemize neden oldu. Lezyon, etrafındaki mukozadan dikkatlice ayrılarak çıkartıldı (Resim 3).

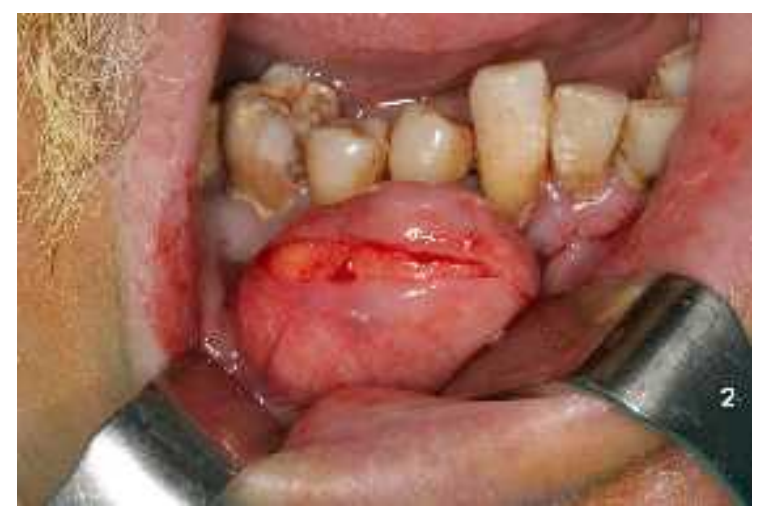

Resim 2. Lezyon üzerinden yapilan mukozal insizyon.

Histopatolojik incelemede lobüler adipoz doku ve olgun adipositler gözlendi. $\mathrm{Bu}$ durum da lipom tanımızı doğruladı.
Postoperatif dönemde herhangi bir problemle karşılaşılmadı ve iyileşme sorunsuz gerçekleşti (Resim 4).

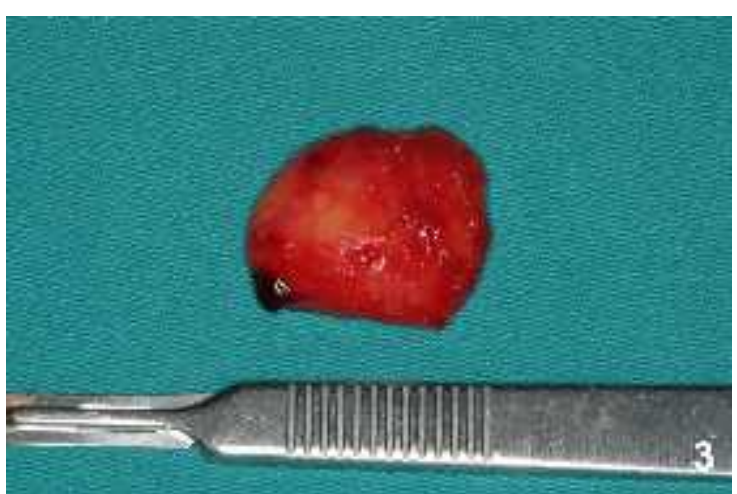

Resim 3. Enükle edilmiş lipom.

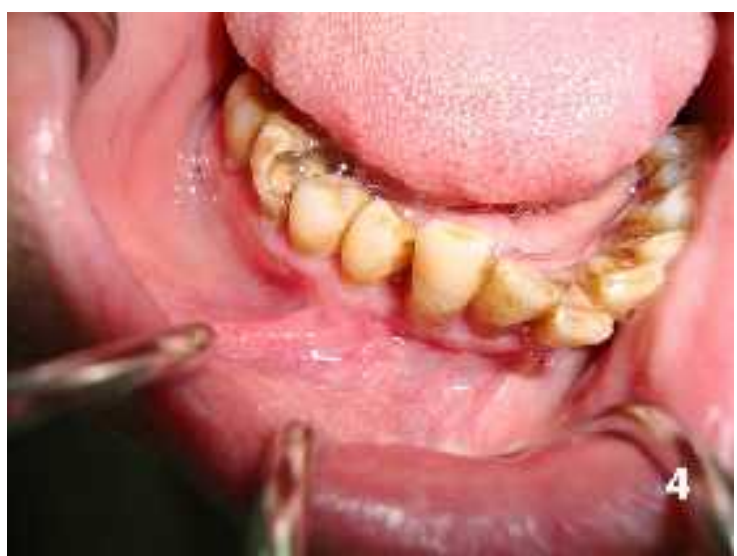

Resim 4. Cerrahiden sonraki üçüncü ay.

\section{TARTIŞMA}

Yağ doku tümörleri erişkinlerde en sık rastlanan yumuşak doku neoplazmı olmakla beraber, birçok lipom herhangi bir semptom vermeden gelişir. ${ }^{7}$ Diğer taraftan içlerinde iğsi hücreli, pleomorfik lipom, lipoblastoma ve intramüsküler lipomun bulunduğu bir grup yağ dokusu tümörünün teşhis edilmesi zordur ve bu lipomlar liposarkomlarla karıştırılabilir. ${ }^{7}$ Lipomların etiyolojik faktörleri arasında birçok şey siralanabilir; travma, enfeksiyon, kronik irritasyon, heredite, yağ dejenerasyonu, kas hücrelerinin metafazı ve lipoblastik embriyonik hücre yuvalanması. ${ }^{6,8,9}$

Klinik olarak lipomlar, yüzeyi pürüzsüz bir mukoza ile kaplı, ağrısız ve yavaş 
büyüyen yumuşak, hamur kıvamında kitleler olarak izlenirler ve ultrasonografi, bilgisayarlı tomografi yada manyetik rezonans görüntülemesi ile belirlenebilirler. ${ }^{10,11}$ Baz1 durumlarda lipomlar akışkan nodüller tarz dada izlenebilir. ${ }^{9}$ Lipomlar, oral mukoza da genellikle bukkal sulkusta ve dil tabanında, 40 yaş ve üzeri kişilerde, kadın erkek ayrımı yapmadan gözlenir. ${ }^{1} \mathrm{Bu}$ olguda ki hastamızın yaşının 58 ve lezyonun bukkal mukozada olması literatür ile örtüşmektedir.

Lipomlar morfolojik olarak iki grupta toplanır. Bunlar; derin dokuları etkileyen diffüz form ve yüzeyel olan kapsüler formlardır. $^{4,12}$ Benign yağ dokusu tümörleri genel olarak klasik lipom ve diğer lipom çeşitleri adı altında iki grupta sinıflandırılır. Lipom çeşitlerine örnek olarak anjiolipom, kondroid lipom, myolipom ve spindle cell/pleomorfik lipom verilebilir. ${ }^{13} \mathrm{Bu}$ olgumuzdaki lezyon klasik lipom grubunda yer almakla beraber kapsüler form yapısındadır. Bu bilgiyi histolojik inceleme de doğrulamıştır.

Yüzeyel lipomlar belirli bir büyüklüğe ulaşmadıkça hastaya herhangi bir rahatsızlık vermezler. Ne zamanki büyük boyutlara ulaşırlar o zaman konuşma bozukluğuna, çiğneme güçlüğüne, hasta protez kullanıyorsa tutuculuğun azalmasına, travmaya bağlı ülserasyona, enfeksiyona ve ağriya neden olabilirler. ${ }^{14,15}$ Olgumuzda da hastanın herhangi bir şikayeti bulunmamaktaydı sadece estetik nedenlerden dolayı eksize edildi.

Mikroskobik olarak normal yağ dokusu ile lipomları ayırt etmek zordur bu yüzden klinisyen laboratuvar biyopsi örneği gönderirken mutlaka klinik görünüşü hakkında da detaylı bilgi vermelidir. ${ }^{3}$ Genellikle oral lipomların bütün histolojik çeşitleri için tedavi cerrahi eksizyondur ve rekürrens gözlenmez. ${ }^{1}$ Bizim vakamızda olduğu gibi, lipomlar enükleasyon ile tedavi edilebilirler. Vakada lezyon üzerinden $3 \mathrm{~cm}$ 'lik bir insizyon yapıldı ve küret yardımıyla lezyon bağlı olduğu dokudan uzaklaştırıldı.

\section{KAYNAKLAR}

1. Fregnani ER, Pires FR, Falzoni R, Lopes MA, Vargas PA. Lipomas of the oral cavity: clinical findings, histological classification and proliferative activity of 46 cases. Int J Oral Maxillofac Surg 2003;32:4953.

2. Trandafir D, Gogalniceanu D, Trandafir V, Caruntu ID. Lipomas of the oral cavity - a retrospective study. Rev Med Chir Soc Med Nat Iasi 2007;111:754-758.

3. Bandeca MC, de Padua JM, Nadalin MR, Ozorio JE, Silva-Sousa YT, da Cruz Perez DE. Oral soft tissue lipomas: a case series. J Can Dent Assoc 2007;73:431-434.

4. Epivatianos A, Markopoulos AK, Papanayotou P. Benign tumors of adipose tissue of the oral cavity: a clinicopathologic study of 13 cases. J Oral Maxillofac Surg 2000;58:11131117.

5. Lombardi T, Odell EW. Spindle cell lipoma of the oral cavity: report of a case. J Oral Pathol Med 1994;23:237-239.

6. De Visscher JG. Lipomas and fibrolipomas of the oral cavity. J Oral Maxillofac Surg 1982;10:177181.

7. Chung ED, Cavazzana AO, Fassina AS. Tumors of adipose tissue, in Ninfo V, Chung EB, Cavazzana AO (eds): Tumors and Tumorlike Lesions of the Soft Tissues. New York, NY, Churchill Livingstone, 1991; 67-89.

8. Gray AR, Barker GR. Sublingual lipoma: report of an unusually large lesion. J Oral Maxillofac Surg 1991;49:747-750.

9. Tan MS, Singh B. Difficulties in diagnosing lesions in the floor of the mouth - report of two rare cases. Ann Acad Med Singapore 
2004;33:72-76.

10. Ahuja AT, King AD, Kew J, King W, Metreweli C. Head and necklipomas: sonographic appearance. Am J Neuroradiol 1998;19:505-508.

11. Sakai T, Lida S, Kishino M, Okura M, Kogo M. Sialolipoma of thehard palate. J Oral Pathol Med 2006;35:376-378.

12. Gnepp DR. Diagnostic surgical pathology of the head and neck. Philadelphia: WB Saunders 191-194.

13. Fletcher CDM, Unni KK, Mertens F. Adipocytic tumors. In: Pathology and genetics: tumours of soft tissue and bone. World Health Organization classification of tumours. Lyon, France: IARC Press; 2002;9-46.

14. Chidzonga M.M., Mahomva L., Marimo C.:Gigantic tongue lipoma: a case report. Med Oral Pato Oral Cir Bucal 2008;11:437-439.

15. Del Castillo Pardo De Vera JL, Cebrian Carretero JL, Gomez Garcia E. Chronic Lingual ulceration caused by lipoma of the oral cavity: case report. Med Oral 2004;2:166-167. 